\title{
Macroeconomic Effects of Exogenous Fiscal Policy Shocks in Pakistan: A Disaggregated SVAR Analysis
}

\author{
KASHIF MUNIR * \\ NIMRA RIAZ ${ }^{* *}$ \\ University of Central Punjab
}

Received: November, 2018

Accepted: September, 2019

\begin{abstract}
This paper analyzes the effects of fiscal policy shocks on a set of macroeconomic variables in Pakistan. The study adopts the SVAR framework and uses quarterly data of Pakistan from 1976:Q1 to 2018:Q4. Fiscal policy shocks are identified by incorporating the elasticity of fiscal variables as well as by taking decision lags in policy formulation to economic activity. The results showed that an increase in government developmental expenditure increases real GDP more than current expenditure, while current expenditure increases prices and developmental expenditure reduces prices. Prices are positively related with subsidies and defence expenditure, while negatively related with expenditure on social services. Tax revenue increases real GDP more than non-tax revenue, while tax revenue and non-tax revenue are both positively related with prices and negatively related with interest rate. An increase in direct tax has positive impact on prices and interest rate and negatively related with real GDP, while indirect tax is positively related with real GDP and negatively related with interest rate. Prices are positively related with excise duty, sales tax, and tax on international trade. Results support the Keynesian view that fiscal policy is a beneficial mechanism to stabilize the economy and stimulate economic activity at the cost of inflation. Government has to channelize the expenditures into productive means, while adopt the strict policy of accountability for the generation and collection of revenue to lead the economy on the path of prosperity.
\end{abstract}

Keywords: Fiscal Policy, Government Expenditures, Government Revenues, SVAR, Pakistan.

JEL Classification: C32, E62, H30.

\section{Introduction}

In economic theory, the systematic role of fiscal policy is sustainable economic growth and development through wisely designed tax system and spending (Hemming et al., 2002).

\footnotetext{
* ORCID ID: 0000-0003-0185-4350.

** ORCID ID: 0000-0001-9922-7691.
} 
Fiscal Policy is one of the main important mechanism available to government for intervention and influence the real economy. Government intervention plays an important role to stabilize and alleviate any threat to the economy. Potential level of output, effective distribution of resources and income can only be achieved through revenues and spending adjusted by the government. Role of fiscal policy in developed economies are to intensify the rate of capital formation and marginal propensity to save by decreasing the level of consumption. However, the aim of fiscal policy in emerging economies are to divert the unproductive resources to productive one as well as the creation of equitable distribution of income (Popa and Codreanu, 2010). In recent years, IMF is focusing on the fiscal stimulus along with easy monetary policy in response to downturn of global economic growth. Fiscal policy can effects distribution of wealth, aggregate demand, and economic capacity to produce goods and services.

Keynesian and neoclassical school of thoughts have different perception about the effects of fiscal policy. Both theories found that output increases when unproductive expenditure financed through increase in lump-sum tax, while the consumption response is different in both the theories. Neoclassical model argues that when government spending financed through increase in non-discretionary taxes then the wealth of households deteriorated, which eventually lead towards depreciation in consumption of household by increasing the labor supply and output (Baxter and King, 1993). According to Keynesian perspective, positive response of household consumption to increase in government spending is achieved by incorporating the price rigidities and non-Ricardian consumers (Gali et al., 2007).

Literature follows different identification approaches to identify the effects of fiscal policy on macroeconomic variables. Perotti (2005) classified the following four approaches used in the literature to identify the shocks of fiscal policy; (a) use of dummy variables for identification of fiscal shocks which capture specific episodes (Burnside et al., 2000; Ramey and Shapiro, 1998; Edelberg et al., 1999); (b) imposition of sign restriction on the impulse response function (Mountford and Uhlig, 2009); (c) identification of fiscal shocks based on Cholesky ordering (Favero 2002; Fatas and Mihov, 2001), (d) fiscal policy shocks are identified by incorporating the elasticity of fiscal variables as well as by taking decision lags in policy formulation to economic activity (Blanchard and Perotti, 2002; Perotti, 2005).

The basic objective of this study is to analyze the effects of fiscal policy shocks on a set of macroeconomic variables within structural VAR model in Pakistan. The paper uses the last approach for identification of fiscal policy shocks i. e. considering decision lags in policy formulation and elasticity of fiscal variables to economic activity. The reason to follow this restriction is that it provides a useful information about tax and transfer system as well as timing of tax collection, as well as, it provides the distinguishing nature of different fiscal policy shocks and accordingly better to estimate their effects. The major importance of this study is to provide better understanding and information to stakeholders. This study is useful to find the impact of government expenditure and revenue on Pakistan economy at large.

The remaining paper is organized as follows: Section 2 describes the literature review. Section 3 describes data and methodological problems related to specification and identifica- 
tion of SVAR model. Section 4 explains the results. Concluding remarks and policy recommendations are discussed in section 5.

\section{Literature Review}

Edelberg et al. (1999) analyzed the consequences of an exogenous increase in US government purchases in US economy. They found that increase in government expenditure lead to increase the nonresidential investment, output and employment, while residential investment, real wages, and consumption expenditure falls. Blanchard and Perotti (2002) examined the impact of government spending and taxes in US by using SVAR framework. They found that a positive shock in taxes and spending have positive effect on output respectively, while negatively affect investment. Perotti (2005) examined the effect of fiscal policy on GDP, inflation and interest rate in five OECD countries by using structural VAR approach. Results of the study showed that fiscal policy has lesser effect on GDP, while tax cut works faster or more effectively than the increase in spending. The study concluded that effects of government spending shocks and tax cuts on GDP and its components have become substantially weaker over time.

De Castro (2006) examined the effects of fiscal policy in Spain by using VAR framework. Results of the study showed that a positive shock in fiscal policy has significant impact on GDP, private consumption, private investment, interest rates and prices in Spain. Giordano et al. (2007) analyzed the relationship between government spending, revenues and macroeconomic variables in Italy by employing the VAR approach. They found that jolts to government expenditure have stabilizing impact on economic activity, while public wages have no important influence on GDP and employment in short run and shocks to net revenue have negligible effects on all macroeconomic variable. Khalid et al. (2007) examined the transmission mechanism and fiscal policy reaction function in Pakistan by using VAR and generalized method of movement. The results of the study showed that anti-cyclical behavior is shown by government expenditure in recessionary period of time but have insignificant response in the boom. On the other hand, pro-cyclical behavior is shown by taxes in boom as well as in recession.

De Castro and De Cos (2008) analyzed the effect of exogenous fiscal shocks in Spain by employing the VAR framework. They found that an increase in government expenditures have positive effects on output, inflation, and public deficit in short term, while lower output in the medium and long term. Ali and Ahmed (2010) analyzed the effect of fiscal policy on economic growth of Pakistan. The results showed that fiscal deficit positively effects economic growth up to a certain threshold level and beyond that threshold level fiscal deficit negatively effects economic growth. Subhani and Ali (2010) examined the relationship between inflation rate, tax rate and balance of trade in Pakistan from 1979 to 2009. The result of the study showed that there is no significant association between tax and inflation but tax rate has significant impact on the balance of trade.

Tenhofen et al. (2010) analyzed the impact of fiscal policy in Germany by using SVAR analysis. Results depicted that government expenditure shock increases private consumption 
and output, while private investment decreased insignificantly. Moreover, aggregate direct taxes lower output significantly, while indirect taxes have minor effects on output. Auerbach and Gorodnichenko (2012) examined the impact of fiscal multiplier in US economy especially in the era of recession from 1947Q1 to 2008Q4. They found that fiscal policy is more effective in recession, while defence expenditure have the largest fiscal multiplier. Paredes et al. (2014) analyzed the impact of fiscal policies in Euro area as well as association among fiscal and monetary policy from 1980:Q1 to 2012:Q4. Results showed that government revenue depicts pro-cyclical and strong behaviour during fluctuation of business cycle, while GDP responds with a lag of twelve to eighteen months in Euro area. Romer and Romer (2014) analyzed the fluctuation in marginal income tax rate on taxable income in US in interwar period from 1920 to 1930 . They found that fluctuation in the elasticity of taxable income to change in log after tax share is positive and small, while business formation have the largest effect.

Alesina et al. (2018) examined different models of deficit reduction (austerity). Results depicted that deficit reduction policies based on spending cuts are much costly as compared to tax based adjustments in short run. Munir and Riaz (2019a) analyzed the relationship between fiscal policy and macroeconomic stability as well as channel through which macroeconomic stability achieved by fiscal policy in South Asian countries. They found that automatic stabilizers and cyclical policy have destabilizing impact, whereas discretionary policy has stabilizing impact in South Asian countries. Munir and Riaz (2019b) analyzed the effects of fiscal policy on macroeconomic variables in Pakistan from 1976:Q1 to 2017:Q4. They found that an increase in government expenditures lead to an increase in private consumption and prices after three quarters, while private investment follows declining trend. Private consumption and interest rate are negatively related with taxes, while, private investment and prices are positively related with taxes.

In sum, literature provides both positive and negative effects of fiscal policy on macroeconomic variable. However, this study is different from other studies on three perspectives: Firstly, disaggregated effects of fiscal policy are analyzed on macroeconomic variables in Pakistan. Secondly, structural vector autoregressive (SVAR) approach is utilized with identification of fiscal shocks by considering decision lags in policy formulation and elasticity of fiscal variables to economic activity. Lastly, this study is used to find out the large number of frictions and shocks of fiscal policy which are designed to capture the time series properties of large macroeconomic data.

\section{Data and Methodology}

The study uses quarterly data of Pakistan from 1976:Q1 to 2018:Q4. Data of government expenditure is disaggregated into current and developmental expenditure. Moreover, current expenditure is further disaggregated into defence expenditure, expenditure on subsidies, and expenditure on social services (i.e. expenditure on social economic, and educational services). On the other hand, revenue is divided into tax and non-tax revenue. Tax revenue is further disaggregated into direct and indirect taxes, and indirect taxes disaggregated into 
excise duty, sales tax, surcharges, and tax on international trade. Data of all these variables have been taken from State Bank of Pakistan (SBP) and Pakistan Economic Survey (various issues). The data of real GDP, prices (proxy by GDP deflator), and interest rate (proxy by call money rate) has been taken from State Bank of Pakistan (SBP) and Pakistan Economic Survey (various issues). All the variables have been taken in the form of log except interest rate. All the variables are available at annual frequency except interest rate which is available at quarterly frequency, while the estimation required quarterly data. Therefore, Denton method is used to interpolate the annual data into quarterly data. Appendix A describes construction of quarterly data in detail as well as compare the results of Denton method and Chow-Lin method. To remove the seasonal effect, the data has been seasonally adjusted by applying $\mathrm{X}-12$ ARIMA procedure.

Structural VAR (SVAR) model is used to analyze the effects of fiscal policy on macroeconomic variables, while Blanchard and Perotti (2002) method is utilized for identification of fiscal policy shocks. Reduced form VAR can be written as:

$$
Y_{t}=C(L) Y_{t-1}+U_{t}
$$

Where $Y_{t}$ is a $N \times 1$ vector of endogenous variables, $C(L)$ is a $N \times N$ matrix of lag polynomial and $U_{t}$ is a $N \times 1$ vector of reduced form innovations which are identically distributed with variance-covariance matrix $\sum U=\mathrm{E}\left(U_{t} U_{t}^{\prime}\right)$.

Amisano and Giannini (1997) suggests the following relationship between reduced-form innovations $U_{t}$ and structural shocks $V_{t}$ as:

$$
A U_{t}=B V_{t}
$$

Where, matrices $A$ and $B$ depict the linear relationship between structural shocks and reduced form residual respectively. For investigating the impact of isolated shocks, structural shocks are assumed to be orthogonal. Consequently, the structural form of the VAR is obtained by multiplying equation (1) by $A$ as:

$$
\begin{gathered}
A Y_{t}=A C(L) Y_{t-1}+A U_{t}=A C(L) Y_{t-1}+B V_{t} \\
Y_{t}=[I-C(L) L]^{-1} A^{-1} B V_{t}
\end{gathered}
$$

When $Y_{t}$ contains integrated variables, the operator $[I-C(L) L]$ is not invertible and representation (4) is not valid as it requires stability of the VAR model. For finite horizon the impulse response matrices and forecast error variance decomposition can be computed in the usual fashion such as the case of stationary stable VAR and impulse responses do not necessarily taper off to zero as the horizon goes to infinity (Lutkepohl, 2005).

The benchmark specification $Y_{t}$ consists of the following five variables real GDP $\left(y_{t}\right)$, GDP deflator $\left(p_{t}\right)$, nominal short-term interest rate $\left(i_{t}\right)$, government expenditure $\left(e_{t}\right)$, and government revenue $\left(r_{t}\right)$. Frequency of the data is crucial for the identification of shock, therefore, quarterly data is used in order to exclude the possibility of discretionary fiscal 
policy actions within one time period. The number of lags are chooses on the basis of LR test and Schwarz information criterion (SIC). This study chooses to estimate the VAR in level, as it gives consistent coefficients of the VAR as well as impulse response functions (Hamilton, 1994; Lutkepohl and Kartzig, 2004). Moreover, cointegrating vectors are hard to find when the model is estimated with many disaggregated time series model.

The estimation proceeds in four steps (Giordano et al., 2007). First step is the estimation of reduced form VAR which produce the reduced form residuals $U_{t}=\left(u_{t}^{y}, u_{t}^{p}, u_{t}^{i}, u_{t}^{e}, u_{t}^{r}\right)$. Perotti (2005) discussed that three types of shocks are generated by linear combination of novelty in fiscal variables $u_{t}^{e}$ and $u_{t}^{r}$. These three types of shocks are as follows: Firstly, the automatic response of government expenditure and revenue to real output, price, and interest rate innovations. Secondly, the systematic, discretionary response of fiscal policy to shocks in macroeconomic variables. Lastly, the random, discretionary fiscal policy shocks, which are the underlying structural shocks to be identified.

Therefore, reduced form equation can be written as:

$$
\begin{aligned}
& u_{t}^{e}=\alpha_{y}^{e} u_{t}^{y}+\alpha_{p}^{e} u_{t}^{p}+\alpha_{i}^{e} u_{t}^{i}+\beta_{r}^{e} v_{t}^{t}+v_{t}^{e} \\
& u_{t}^{r}=\alpha_{y}^{r} u_{t}^{y}+\alpha_{p}^{r} u_{t}^{p}+\alpha_{i}^{r} u_{t}^{i}+\beta_{e}^{r} v_{t}^{e}+v_{t}^{r}
\end{aligned}
$$

Whereas $v_{t}^{e}, v_{t}^{r}$ are structural shocks to government total expenditure and taxes respectively. Government requires more than one quarter to react to macroeconomic shocks, becomes relevant. It depicts that $\alpha_{j}^{i}$ which is the first channel i.e. automatic response of fiscal variables towards macroeconomic development. OLS can not be used to estimate $\alpha_{j}^{i}$, because reduced form residuals are correlated with $v_{t}$. Therefore, study followed Blanchard and Perotti (2002) methodology to use exogenous elasticities of fiscal variables to estimate the model. Appendix B describes the construction of exogenous fiscal policy elasticities as well as table B1 reports the exogenous elasticities of fiscal variables with respect to GDP, prices, and interest rate. Study used exogenous elasticities to measure the cyclically adjusted reduced form fiscal policy shocks as:

$$
\begin{aligned}
& u_{t}^{e, C A}=u_{t}^{e}-\alpha_{y}^{e} u_{t}^{y}-\alpha_{p}^{e} u_{t}^{p}-\alpha_{i}^{e} u_{t}^{i}=\beta_{r}^{e} v_{t}^{t}+v_{t}^{e} \\
& u_{t}^{r, C A}=u_{t}^{r}-\alpha_{y}^{r} u_{t}^{y}-\alpha_{p}^{r} u_{t}^{p}-\alpha_{i}^{r} u_{t}^{i}=\beta_{e}^{r} v_{t}^{e}+v_{t}^{r}
\end{aligned}
$$

This is the second step of estimation procedure. It is necessary to make decision with respect to ordering of fiscal variables in order to find out fiscal shocks. If $\beta_{e}^{r}=0$ is assumed then it means that tax decision comes first, whereas $\beta_{r}^{e}=0$ depicts that decision of expenditure comes earlier. Latter ordering is used in the estimation process, while the reverse ordering process does not affect the results much. In third step, it is possible to estimate $\beta_{e}^{r}$ by OLS and process the structural shocks to the fiscal variables $v_{t}^{e}$ and $v_{t}^{r}$ as illustrated by following two equations:

$$
u_{t}^{e, C A}=v_{t}^{e}
$$




$$
u_{t}^{r, C A}=\beta_{e}^{r} v_{t}^{e}+v_{t}^{r}
$$

This specification allows for immediate response of government revenue to spending shocks. In this regard, the interaction of the expenditure and revenue side of government activity included. In the final step the remaining coefficient of final equation is estimated as:

$$
\begin{gathered}
u_{t}^{y}=\alpha_{e}^{y} u_{t}^{e}+\alpha_{r}^{y} u_{t}^{r}+v_{t}^{y} \\
u_{t}^{p}=\alpha_{e}^{p} u_{t}^{e}+\alpha_{r}^{p} u_{t}^{r}+\alpha_{y}^{p} u_{t}^{y}+v_{t}^{p} \\
u_{t}^{i}=\alpha_{e}^{i} u_{t}^{e}+\alpha_{r}^{i} u_{t}^{r}+\alpha_{y}^{i} u_{t}^{y}+\alpha_{p}^{i} u_{t}^{p}+v_{t}^{i}
\end{gathered}
$$

These equations are estimated by instrumental variable least square in order to account for the correlation of regressors. Structural shock $v_{t}$ are orthogonal and can be used as instruments. $v_{t}^{e}$ and $v_{t}^{r}$ are used as instruments during the estimation of equation (11) yielding the structural shocks to $v_{t}^{y}$. For estimation of equation (12) additional instruments are added by this structural shocks for getting the structural shock to $v_{t}^{p}$. In the last, this shock is combined with the previous three to obtain the instrument for measurement of equation (13). These four steps include all important material for formation of A and B matrices.

$$
\left[\begin{array}{ccccc}
1 & 0 & 0 & -\alpha_{e}^{y} & -\alpha_{r}^{y} \\
-\alpha_{y}^{p} & 1 & 0 & -\alpha_{g}^{p} & -\alpha_{r}^{p} \\
-\alpha_{y}^{i} & -\alpha_{p}^{i} & 1 & -\alpha_{e}^{i} & -\alpha_{r}^{p} \\
-\alpha_{y}^{e} & -\alpha_{p}^{e} & -\alpha_{i}^{e} & 1 & 0 \\
-\alpha_{y}^{r} & -\alpha_{p}^{r} & -\alpha_{i}^{r} & 0 & 1
\end{array}\right]\left[\begin{array}{c}
u_{t}^{y} \\
u_{t}^{p} \\
u_{t}^{i} \\
u_{t}^{e} \\
u_{t}^{r}
\end{array}\right]=\left[\begin{array}{ccccc}
1 & 0 & 0 & 0 & 0 \\
0 & 1 & 0 & 0 & 0 \\
0 & 0 & 1 & 0 & 0 \\
0 & 0 & 0 & 1 & 0 \\
0 & 0 & 0 & \beta_{g}^{t} & 1
\end{array}\right]\left[\begin{array}{c}
v_{t}^{y} \\
v_{t}^{p} \\
v_{t}^{i} \\
v_{t}^{e} \\
v_{t}^{r}
\end{array}\right]
$$

The restriction which is imposed on these two matrices implies that the order condition is satisfied and the model is just identified. Variance and covariance matrices of reduced form residual and innovation $\mathbb{\Sigma}_{U}$ and structural shocks $\sum_{V}$ can be depicted from following expression:

$$
\sum_{U}=A^{-1} \mathrm{~B} \sum_{V} B^{\prime}\left(A^{-1}\right)^{\prime}
$$

The equation shows that $A, B$ and $\mathbb{\Sigma}_{V}$ have no more unknown parameters than $\Sigma_{U}$. The latter being symmetric has $N(N+1 / 2)$ non-redundant elements. In this estimation $N=5 \mathrm{im}$ plies that 15 distinct parameters have to be identified. In the above matrices, 9 parameters of matrix $A$ (first three rows), 5 diagonal matrices of $\Sigma_{V}$ and 1 parameter of matrix $B$ have to be estimated. The remaining parameters are set to zero or one and equal to exogenous elasticities (last two rows of $A$ ). As a whole the just identified model has 15 parameters to be identified.

Study used the bootstrap procedure in order to take account of the full estimation uncertainty of the four-step estimation approach. Study plot $90 \%$ confidence intervals which is compared to one-standard deviation bands in Blanchard and Perotti (2002) which depicts the wide confidence interval. In this process the point estimation as well as $90 \%$ point wise bootstrap confidence intervals based on 5000 replication following bootstrap after bootstrap procedure of Kilian (1998). Moreover, impulse response function are plotted for 20 quarters. 
As this study measured the VAR in level and there are unit roots or near unit roots in the system. Therefore, impulse responses of long period are inconsistent because they tend to random the variables and do not show true impulse responses (Phillips, 1998).

\section{Results}

\subsection{Government Expenditures and Tax Composition in Pakistan}

Figure 1 demonstrates the trend of total expenditures, current expenditures, and developmental expenditures as a percentage of GDP from 1976 to 2018. The trend of total government expenditures shows mix behavior from 1976 to 1988, while it shows a sharp decline from 1992 to 2001, however, it shows a significant increase from 2006 to 2018. Current expenditures also shows similar behavior to total government expenditures. Developmental expenditure shows a gradual decrease from $10 \%$ to $2 \%$ from 1976 to 2001, while it shows slight increase afterwards and remain below 5\% from 2001 to 2018.

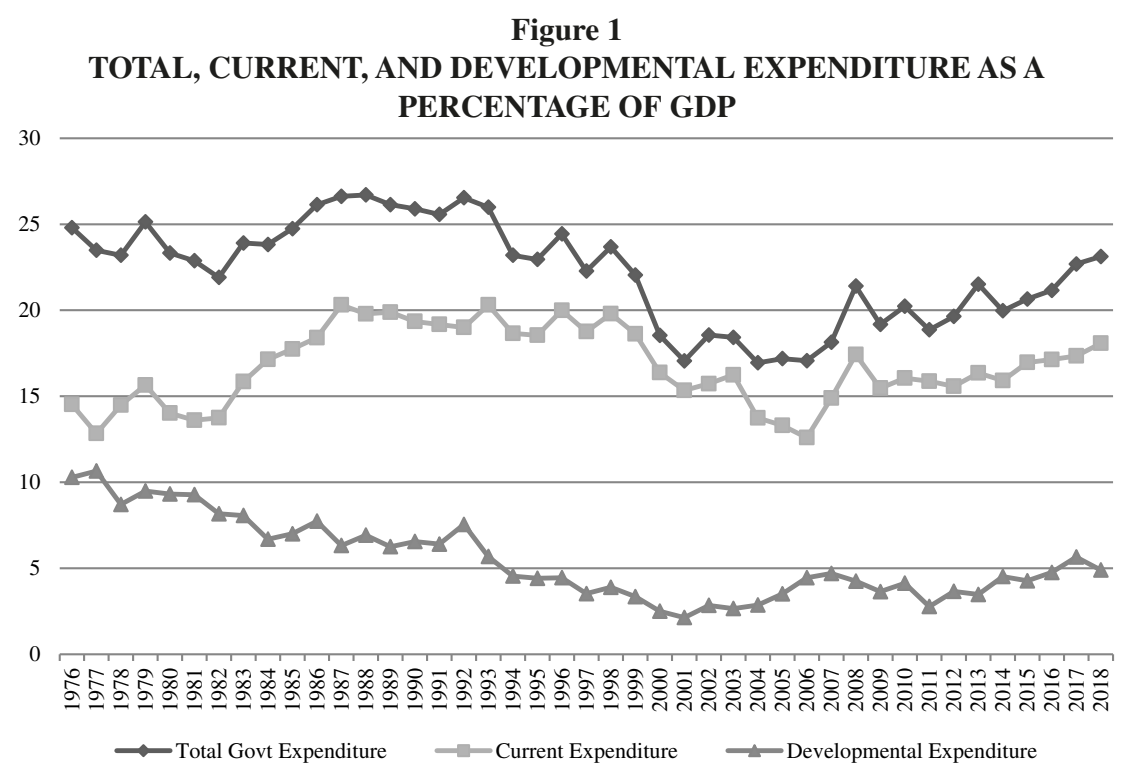

Figure 2 demonstrates the trend of direct tax, indirect tax, non-tax revenue, and total revenue as a percentage of GDP from 1976 to 2018. Direct tax remains below 4\% from 1976 to 2015 , while it shows a gradual increase afterwards. However, indirect tax remains $10 \%$ to $12 \%$ of GDP from 1976 to 1996, while it shows a declining trend from 1999 to 2007 and afterwards shows a sharp increase. Total government revenue follows similar oscillation to indirect taxes. Non-tax revenue remains higher than direct tax from 1976 to 1994, while it shows ups and down afterwards. 
Figure 2

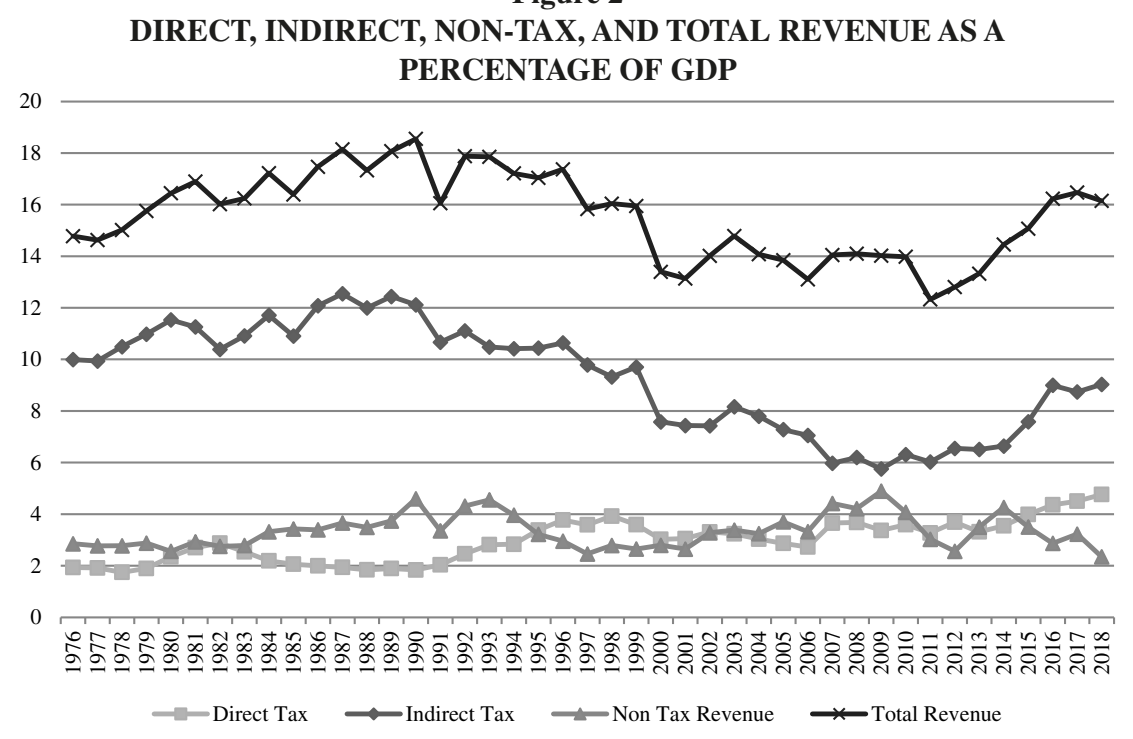

Figure 3 shows the trend of sub-components of indirect taxes i.e. tax on international trade, excise duty, sales tax, and surcharges as a percentage of GDP. Sales taxes was below $1 \%$ in 1976, while it shows a sharp increase from 1986 to 2018. Excise duty and tax on international trade shows a sharp decline over the period. However, surcharges show mix behaviour from 1976 to 2018 .

Figure 3

\section{SUB-COMPONENTS OF INDIRECT TAXES AS A PERCENTAGE OF GDP}

7

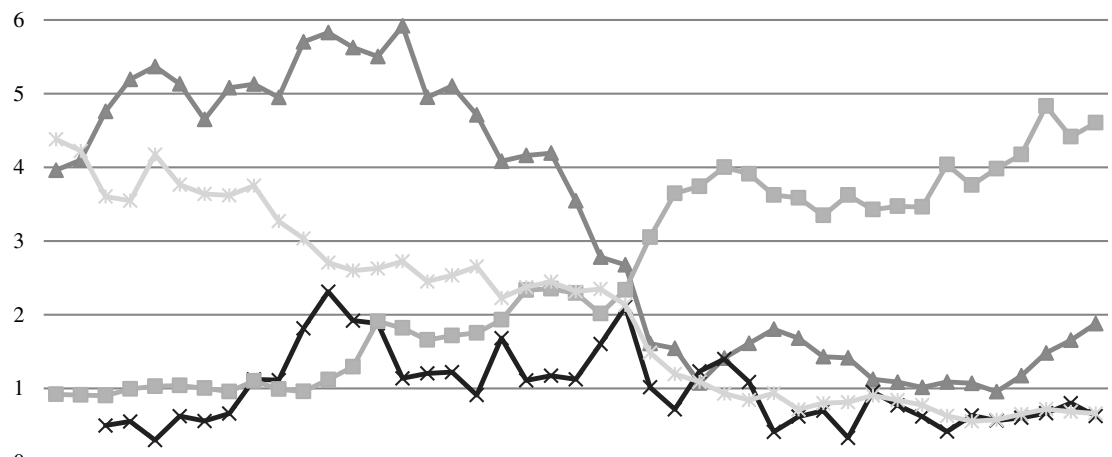

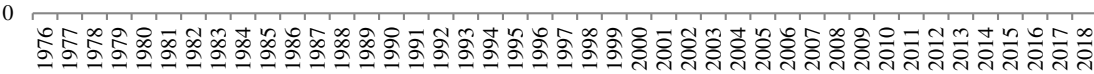

$\longrightarrow$ Taxes on International Trade $\quad *$ Surcharges $\quad-$ Sales Tax $\quad \ldots$ Excise Duty 


\subsection{Baseline Specification}

Figure 4 shows the impulse response of a positive shock in total expenditure and total revenue on GDP, prices, and interest rate. An increase in government total expenditures lead to an increase in real GDP, while the shock start declining after nine quarters. Holmes and Hutton (1990), Aschauer (1989), and Tenhofen et al. (2010) also found the positive effect of government expenditure on real GDP. Prices also show a positive increase with an increase in government expenditure and take seven quarter to decrease. De Castro and De Cos (2008) also found positive effect of expenditure on prices. Moreover, interest rate tends to increase in response to a positive shock in government expenditure and shows decline after six quarters. De Castro and De Cos (2008) also found similar behavior of interest rate to expenditure shock. On the other hand, an increase in government total revenue leads to an increase in real GDP, while the shock start declining after eleven quarters. Prices also show a positive increase with an increase in government revenue and take six quarter to decrease. However, interest rate initially decreases for three quarters in response to a positive shock in government revenue and then shows an increase for the next three quarters. De Castro and De Cos (2008), and Tenhofen et al. (2010) also found similar results. Increased expenditure leads to increase in gross domestic product. Whenever government increases expenditure in productive sector it stimulates the economic growth and prosperity of country.

\section{Figure 4}

\section{IMPULSE RESPONSE OF A POSITIVE SHOCK IN TOTAL EXPENDITURE AND TOTAL REVENUE}

Shocks to Total Expenditure

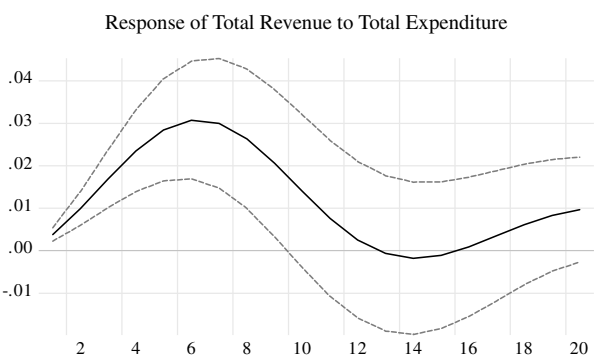

Response of GDP to Total Expenditure

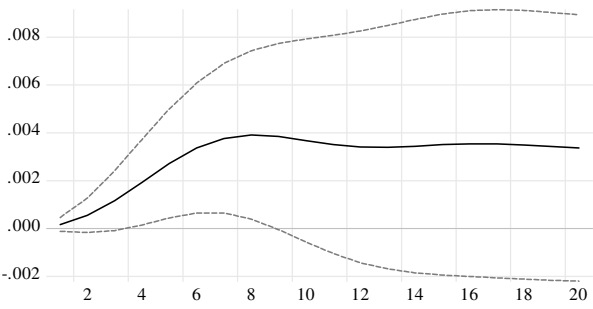

Shocks to Total Revenue

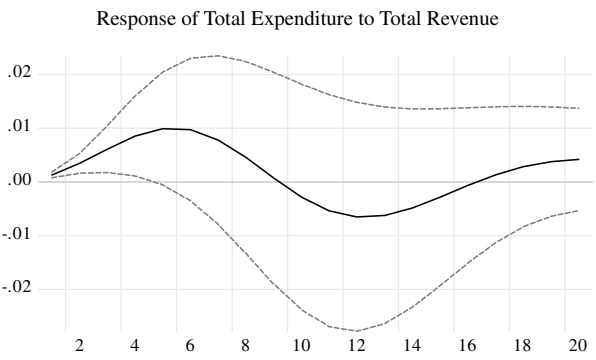

Response of GDP to Total Revenue

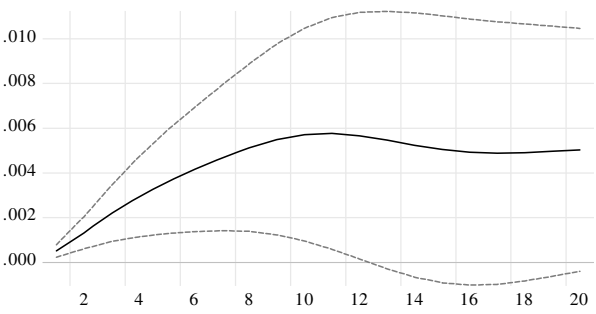


(Continued.)

\section{Shocks to Total Expenditure}

Response of Prices to Total Expenditure

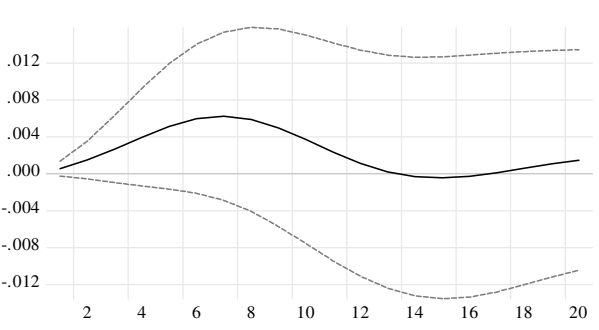

Response of Interest Rate to Total Expenditure

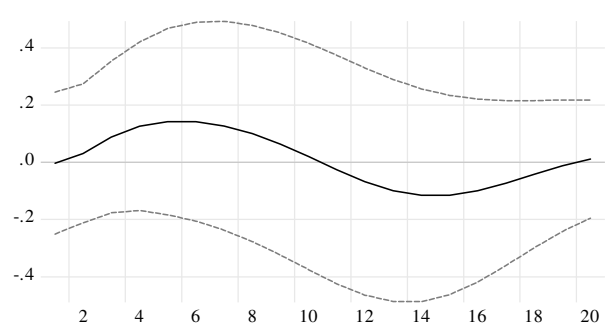

Shocks to Total Revenue

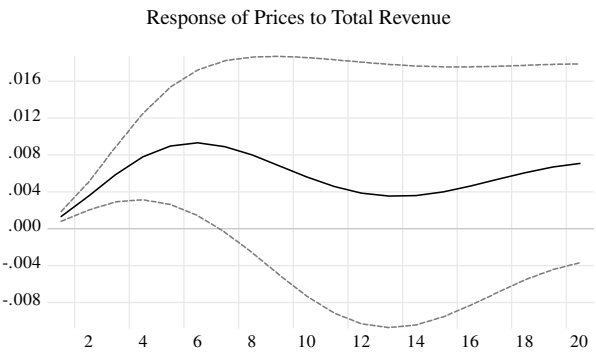

Response of Interest Rate to Total Revenue

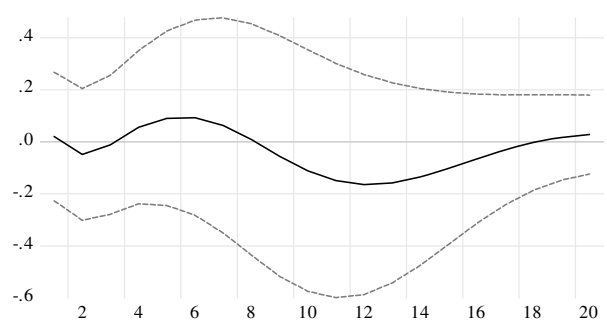

\subsection{Disaggregating Government Expenditure Components}

Government expenditure components are disaggregated into current and developmental expenditure, whereas current expenditure is further disaggregated into defence expenditure, expenditure on subsidies, and expenditure on social services. Figure 5 shows the impulse response of a positive shock in current and developmental expenditure on GDP, prices, and interest rate. An increase in government current expenditures lead to an increase in real GDP. Prices show a positive increase with an increase in government current expenditure and take six quarter to decrease. Interest rate tends to increase in response to a positive shock in government current expenditure and shows decline after three quarters. On the other hand, an increase in government developmental expenditure leads to an increase in real GDP, while the shock start declining after eight quarters. Prices show an initial decrease with an increase in government developmental expenditure and take three quarter to increase. However, interest rate shows an increase in response to a positive shock in government developmental expenditure. Tenhofen et al. (2010) and De Castro and De Cos (2008) also found the similar results. 
Figure 5

\section{IMPULSE RESPONSE OF A POSITIVE SHOCK IN CURRENT AND DEVELOPMENTAL EXPENDITURE}

Shocks to Current Expenditure

Response of GDP to Current Expenditure
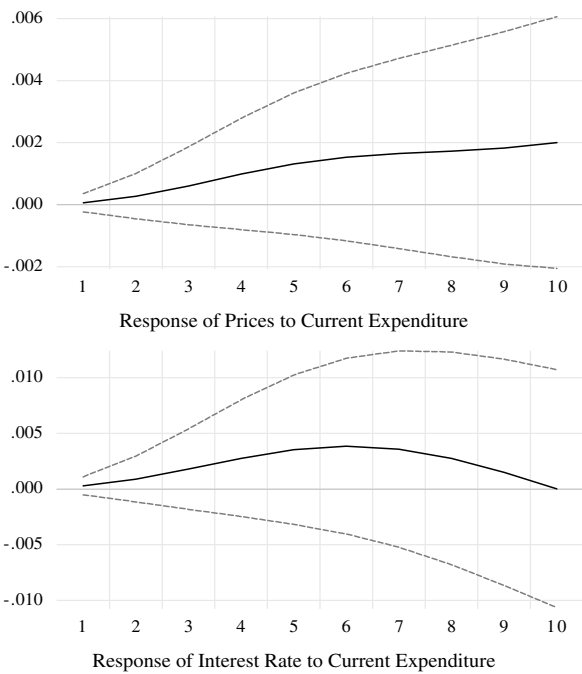

Response of Interest Rate to Current Expenditure

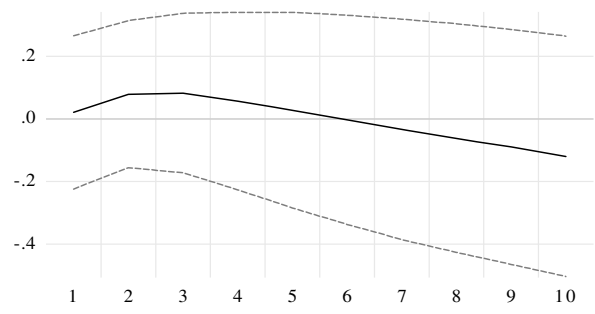

Shocks to Developmental Expenditure
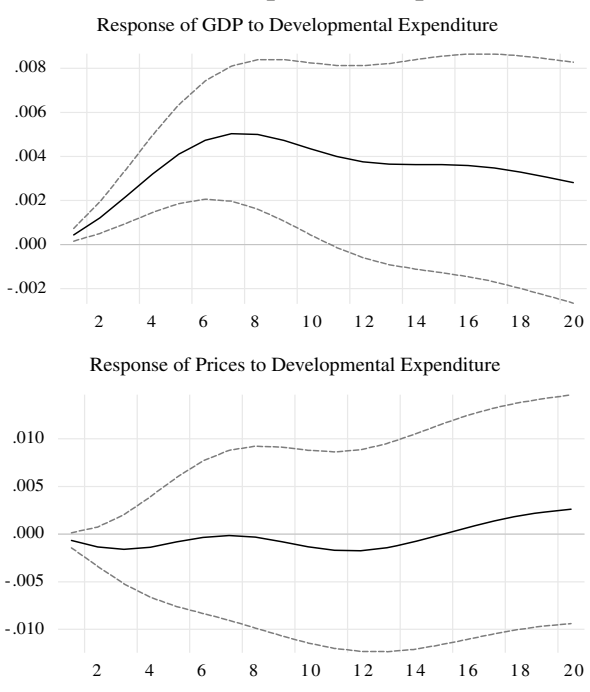

Response of Interest Rate to Developmental Expenditure

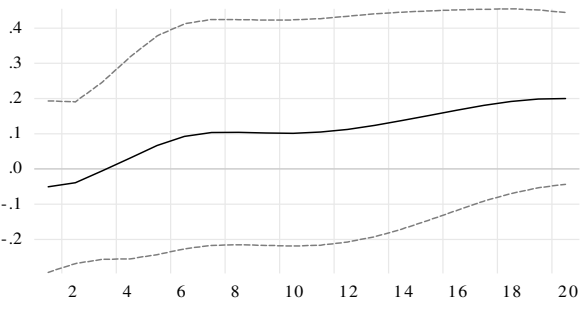

Figure 6 shows the impulse response of a positive shock in expenditure on subsidies, expenditure on social services, and defence expenditure on GDP, prices, and interest rate. An increase in government expenditures on subsidies decrease real GDP initially, and take three quarters to increase. Prices show a sharp positive increase with an increase in government expenditures on subsidies and take eight quarter to decrease. Interest rate declines in response to a positive shock in government expenditures on subsidies and shows increase after three quarters. An increase in government expenditure on social services lead to a persistent increase in real GDP, while the shock start declining after fourteen quarters. Prices show declining trend with an increase in government expenditure on social services. However, interest rate shows decrease in response to a positive shock in government expenditure on social services and shows an increase after five quarters. Real GDP shows an increase after a positive shock in government expenditure on defence. Prices show an increase with an increase in government expenditure on defence and show decline after five quarters. Interest rate shows declining trend with an increase in government expenditure on defence. Similar results are also found by Tenhofen et al. (2010) and De Castro and De Cos (2008). 
Macroeconomic Effects of Exogenous Fiscal Policy Shocks in Pakistan: A Disaggregated...

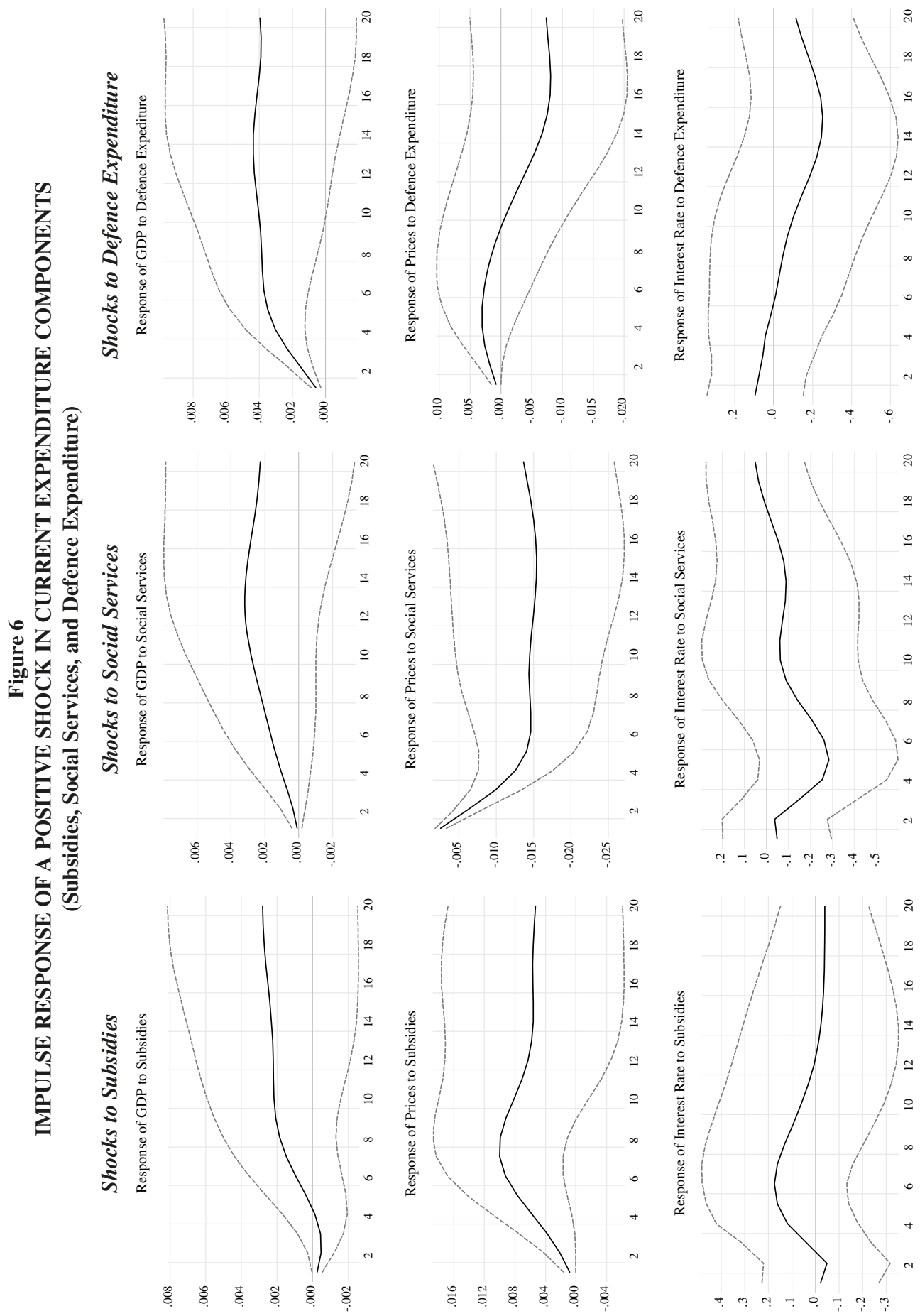




\subsection{Disaggregating Government Revenue Components}

Government revenue components are disaggregated into tax and non-tax revenue, while tax revenue is disaggregated into direct and indirect tax revenue, whereas indirect tax revenue is further disaggregated into excise duty, sales tax, surcharges, and tax on international trade. Figure 7 shows the impulse response of a positive shock in tax and non-tax revenue on GDP, prices, and interest rate. An increase in government tax revenue leads to an increase in real GDP and declines after nine quarters. Prices show a slight positive increase with an increase in government tax revenue and take five quarter to decrease. Interest rate shows a sharp decrease in response to a positive shock in government tax revenue and start increasing after three quarters. Real GDP shows a slight positive increase after an increase in government non-tax revenue and shows increasing trend after nine quarters. Prices also show the same behavior after a positive increase in government non-tax revenue and follow increasing trend after seven quarters. Interest rate shows a decrease in response to a positive increase in government non-tax revenue and takes four quarters to increase. Munir and Sultan (2018) also found positive effect of taxes on real GDP in Pakistan.

Figure 7

IMPULSE RESPONSE OF A POSITIVE SHOCK IN TAX AND NON-TAX REVENUE

Shocks to Tax Revenue

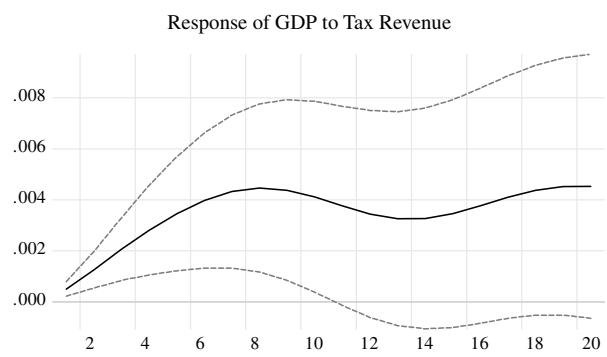

Response of Prices to Tax Revenue

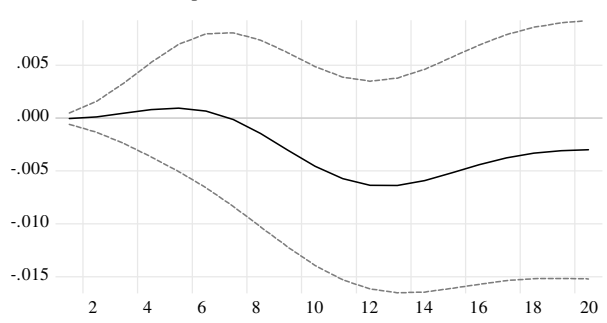

Shocks to Non-Tax Revenue

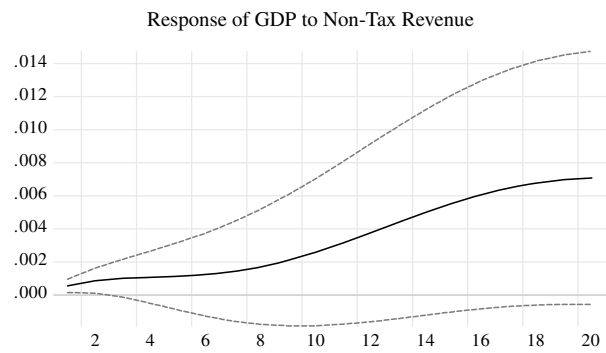

Response of Prices to Non-Tax Revenue

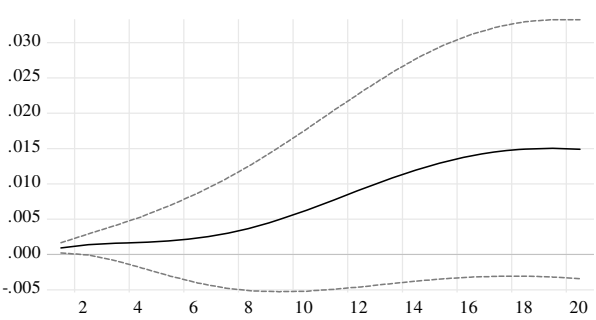



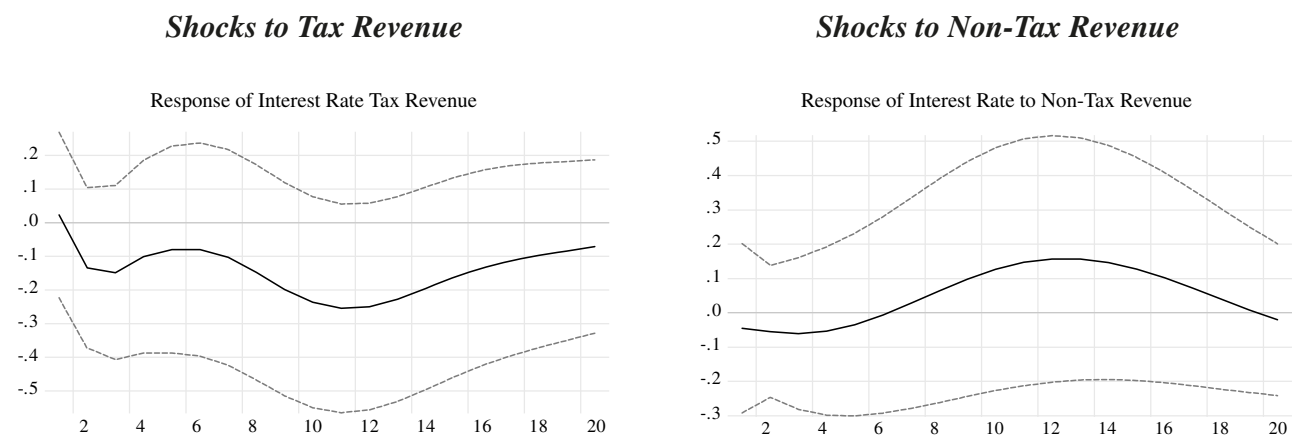

Figure 8 shows the impulse response of a positive shock in direct tax and indirect tax revenue on GDP, prices, and interest rate. An increase in government direct tax revenue leads to decrease in real GDP. Prices show positive increase with an increase in government direct tax revenue. Interest rate shows an increase in response to a positive shock in government direct tax revenue and starts decreasing after six quarters. On the other hand, an increase in government indirect tax revenue leads to an increase in real GDP. Prices show a slight increase after a positive increase in government indirect tax revenue and take five quarter to decrease. Interest rate shows a sharp decrease in response to a positive shock in government indirect tax revenue. Munir and Sultan (2018) found positive relationship between tax revenue and economic growth in Pakistan.

Figure 8

IMPULSE RESPONSE OF A POSITIVE SHOCK IN DIRECT AND INDIRECT TAX

Shocks to Direct Tax

Response of GDP to Direct Tax

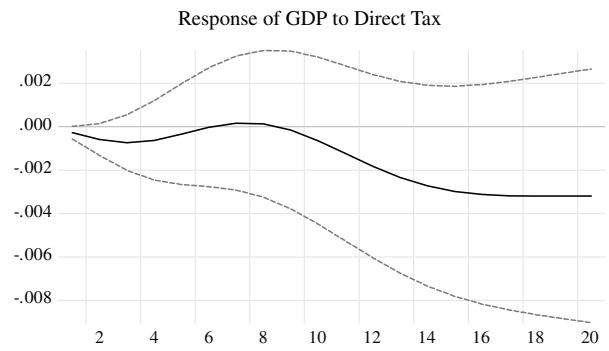

Shocks to Indirect Tax

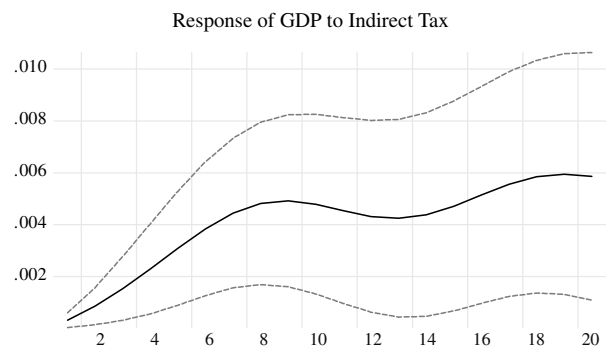


(Continued.)
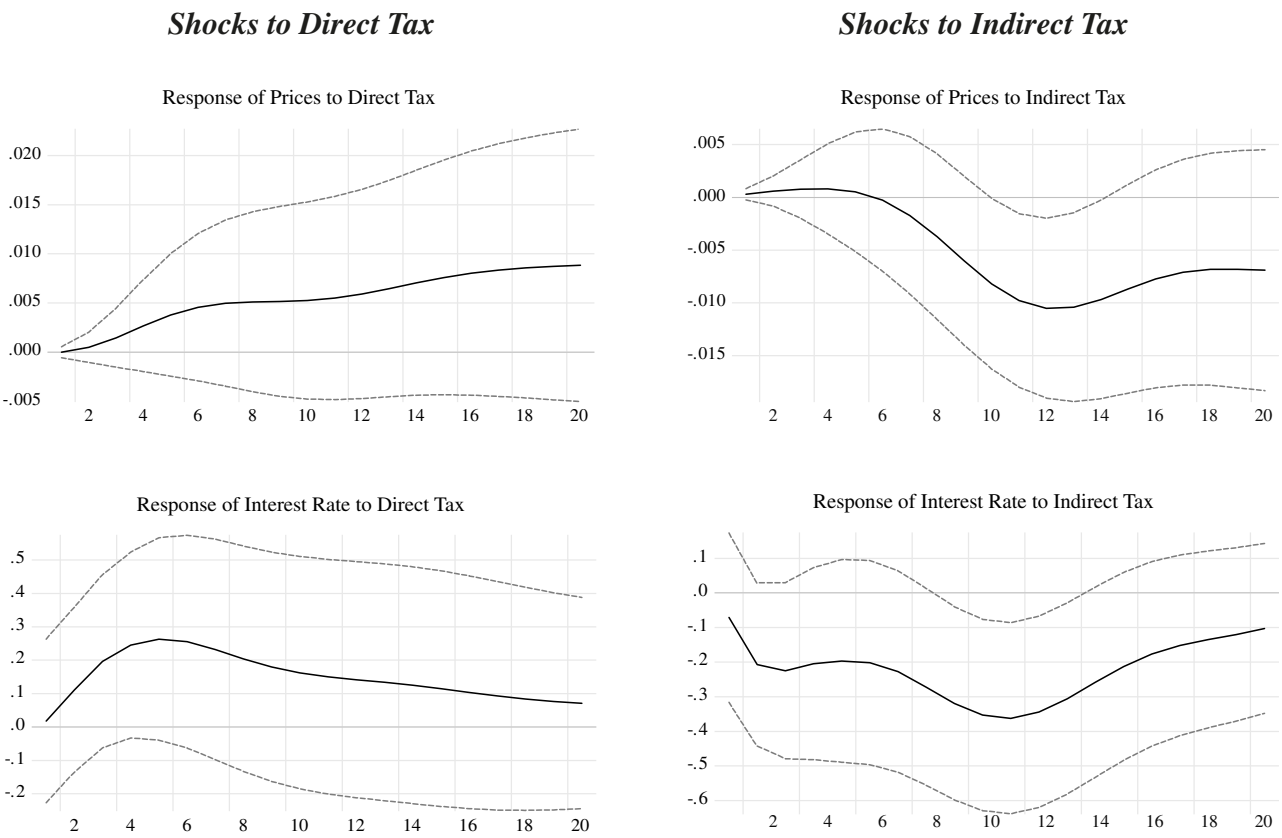

Figure 9 shows the impulse response of a positive shock in sub-components of indirect taxes i.e. excise duty, sales tax, surcharges, and tax on international trade on GDP, prices, and interest rate. An increase in excise duty increases real GDP initially, and takes five quarters to decrease. Prices show a sharp positive increase with an increase in excise duty and take nine quarter to decrease. Interest rate does not show any response for two quarters and then shows sharp increase in response to a positive shock in excise duty and takes five quarters to decrease. Real GDP does not show any response for three quarters and then shows an increase in response to a positive shock in sales tax and takes nine quarters to decrease. Prices show a sharp increase after an increase in sales tax. Interest rate shows a sharp decrease in response to a positive shock in sales tax and takes three quarters to increase.

Real GDP does not show any response for four quarters after a positive shock in surcharges and then shows an increasing trend. Prices show a slight increase after an increase in surcharges and then show decreasing trend. Interest rate shows decrease in response to a positive shock in surcharges and takes six quarters to increase. Real GDP shows an increase after a positive shock in tax on international trade and takes eight quarters to decrease. Prices do not show any significant response for four quarters in response to a positive shock in tax on international trade and then show an increase. Interest rate does not show any significant response for three quarters in response to a positive shock in tax on international trade and then shows an increase. 


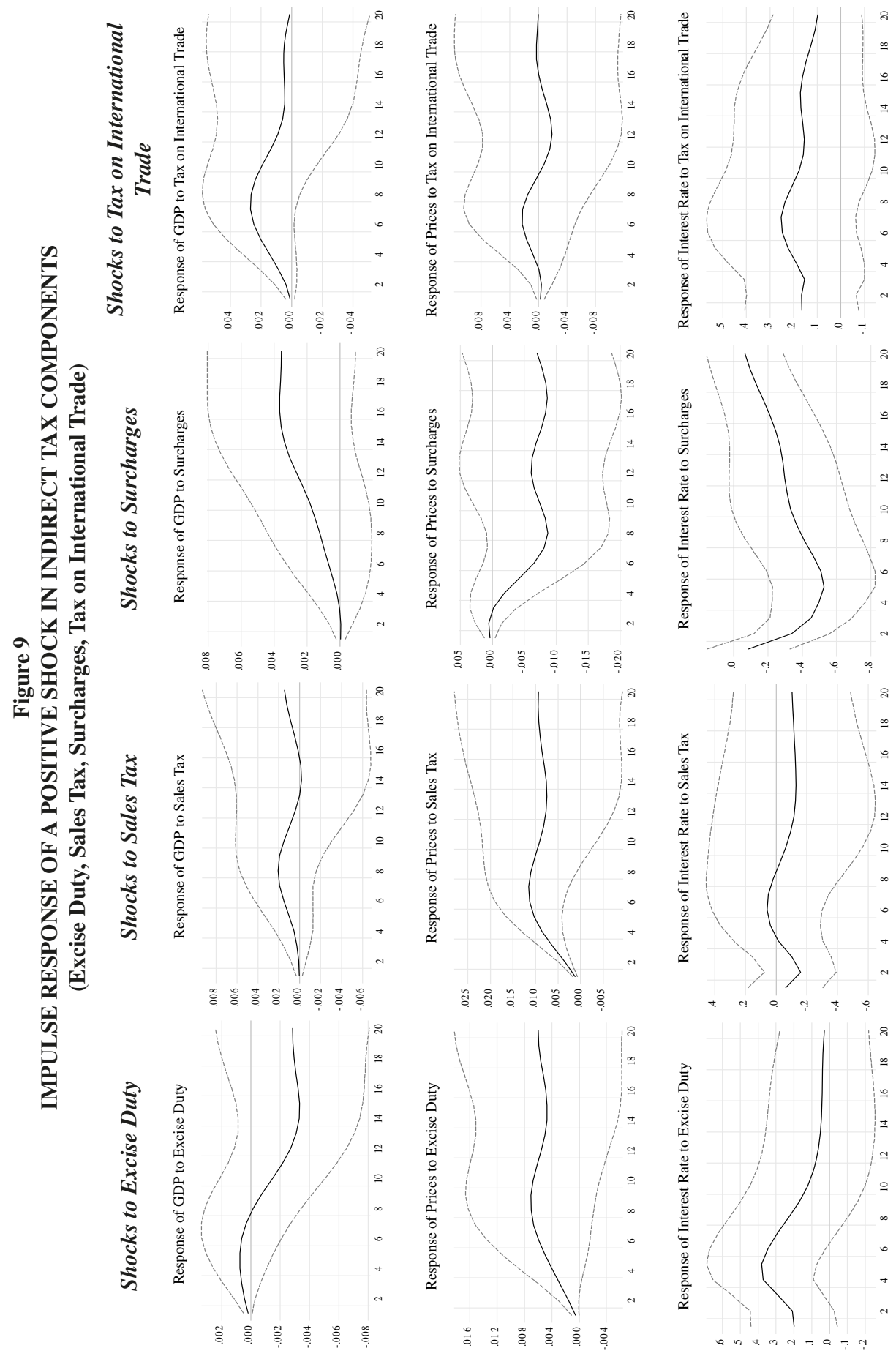




\subsection{Robustness Check}

Different modeling schemes have been used to verify the results. The first alternative specification is following Cholesky identification scheme instead of exogenous elasticities. Figure 10 shows the impulse response of a positive shock in total expenditure and total revenue on GDP, prices, and interest rate. An increase in government total expenditures lead to an increase in real GDP, prices, and interest rate. However, an increase in government total revenue leads to an increase in real GDP, and prices, while interest rate initially decreases for three quarters and then shows an increase. Munir and Riaz (2019b) also found similar results.

Figure 10

\section{IMPULSE RESPONSE OF A POSITIVE SHOCK IN TOTAL EXPENDITURE AND} REVENUE WITH CHOLESKY ORDER
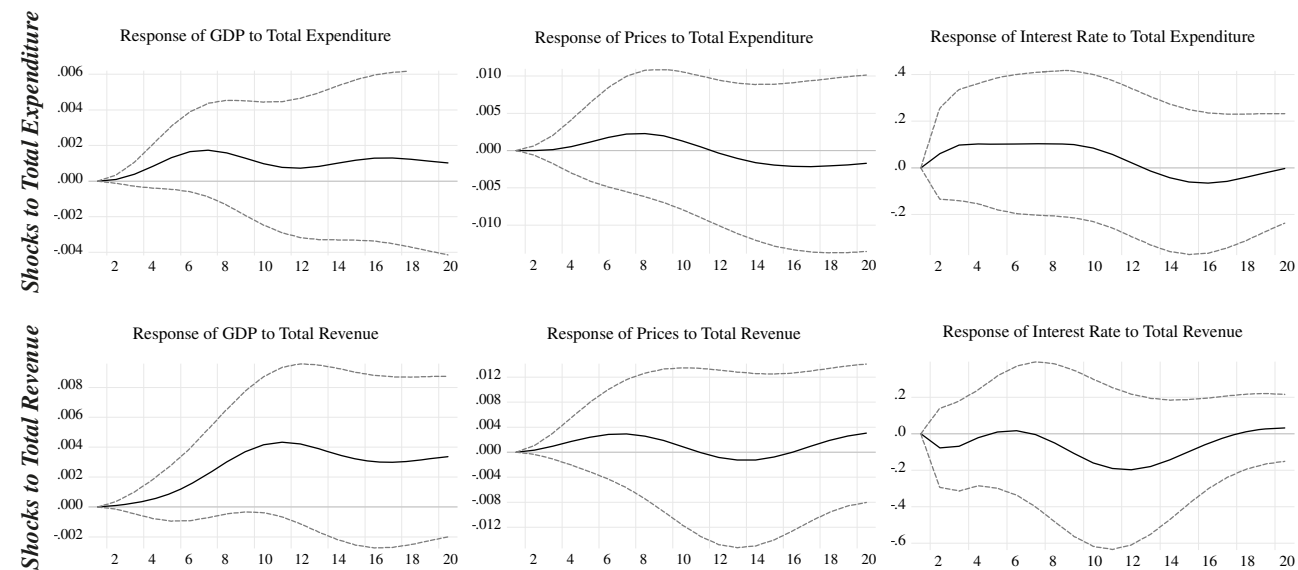

The second alternative specification has estimated the VAR model with trend and trend square in the baseline model. Figure 11 shows the impulse response of a positive shock in total expenditure and total revenue on GDP, prices, and interest rate. An increase in government total expenditures lead to an increase in real GDP, and prices, while interest rate show slight increase. On the other hand, an increase in government total revenue leads to an increase in real GDP, and prices, while interest rate shows a decrease for three quarters and then shows an increase.

Figure 11

IMPULSE RESPONSE OF A POSITIVE SHOCK IN TOTAL EXPENDITURE AND REVENUE WITH TREND AND TREND SQUARE
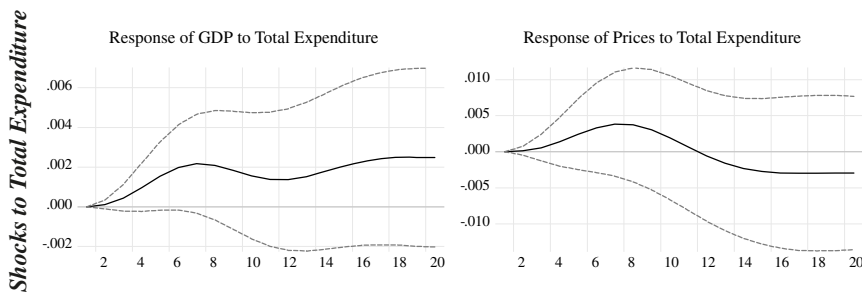

Response of Interest Rate to Total Expenditure

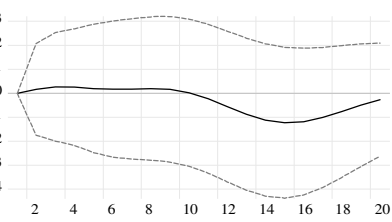


(Continued.)
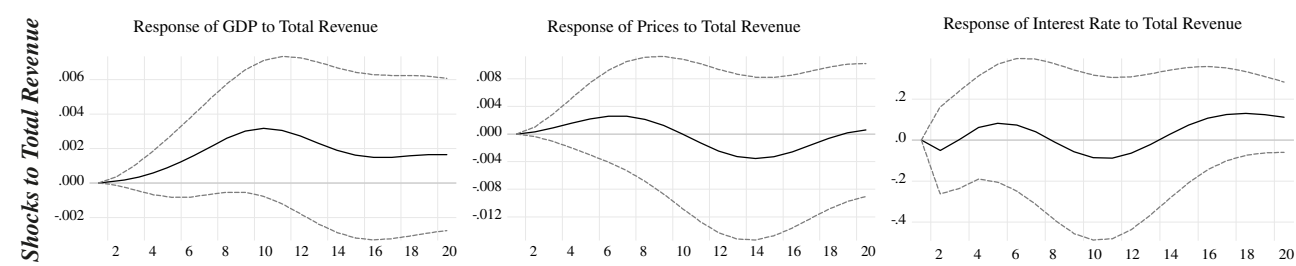

However, in the third alternative specification, the Chow-Lin method is used to interpolate the annual data into quarterly data. Figure 12 shows the impulse response of a positive shock in total expenditure and total revenue on GDP, prices, and interest rate. An increase in government total expenditures lead to an increase in real GDP after four quarters, while prices and interest rate show an instant increase. Moreover, an increase in government total revenue leads to an increase in real GDP, and prices, while interest rate shows an increase after three quarters. Results of all the alternative models are similar to baseline model. Hence, results are robust to other specification and provide similar results.

\section{Figure 12}

\section{IMPULSE RESPONSE OF A POSITIVE SHOCK IN TOTAL EXPENDITURE AND TOTAL REVENUE WITH CHOW-LIN METHOD OF QUARTERIZATION}
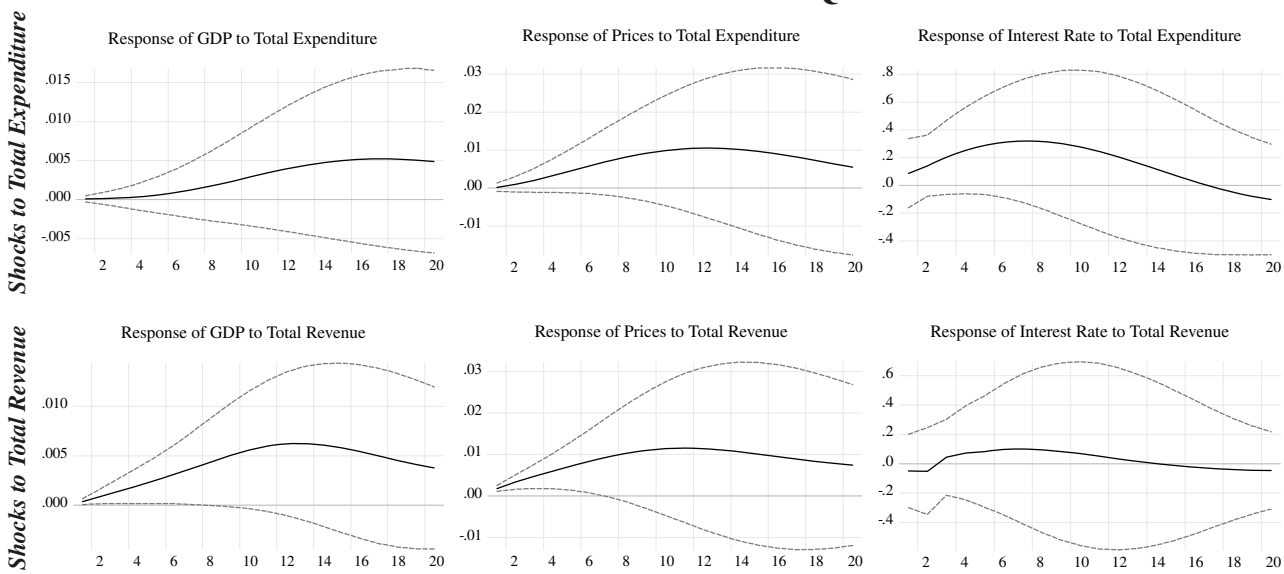

\section{Conclusion}

Government intervention plays an important role to stabilize and alleviate any threat to economy and fiscal policy is one of the main important mechanism available to government for intervention. Spending and revenues are adjusted by the government in order to achieve the potential level of output and effective distribution of resources and income. The objective of this paper is to analyze the effects of fiscal policy shocks on a set of macroeconomic variables within structural VAR framework in Pakistan. The paper uses the Blanchard and Perotti (2002) 
approach for identification of fiscal policy shocks. The main significance of this study is to provide the better understanding and information to stakeholders as well as predict the impact of government revenue and expenditure on the economy at large. The study uses quarterly data of Pakistan from 1976:Q1 to 2018:Q4.

Results showed that an increase in government total expenditures increase real GDP, interest rate, and prices. On the other hand, an increase in current expenditure and developmental expenditure increases real GDP, while developmental expenditure increases real GDP more than current expenditure. Current expenditure increases prices, while developmental expenditure reduces prices. Real GDP decreases with an increase in government expenditure on subsidies, while increases with an increase in social services and defence expenditure. Prices are positively related with subsidies and defence expenditure, while negatively related with expenditure on social services. Interest rate shows mix behavior with different components of current expenditures.

Real GDP has positive relationship with tax and non-tax revenue, while tax revenue increases real GDP more than non-tax revenue. Tax revenue and non-tax revenue are both positively related with prices and negatively related with interest rate. An increase in direct taxes have positive impact on prices and interest rate, while negatively related with real GDP. Indirect taxes are positively related with real GDP and negatively related with interest rate, while prices show slight increase with an increase in indirect taxes. Real GDP is positively related with excise duty and tax on international trade, while it takes three quarters to increase with respect to sales tax and surcharges. Prices are positively related with excise duty, sales tax, and tax on international trade, while it shows decrease after three quarters with respect to surcharges. An increase in surcharges reduce interest rate, while interest rate shows mix behavior with an increase in excise duty, sales tax, and tax on international trade.

These results support the Keynesian view that fiscal policy is a useful tool to stabilize the economy. Government through expenditure expansion can stimulate economic activity in Pakistan at the cost of inflation. In the light of above findings, the study recommend the following policies: Firstly, an active and efficient role of government is required for sustainable economic growth. Secondly, government has to channelize the expenditures into productive means to meet the country's demand rather than to spend on the various unproductive projects. Lastly, government has to adopt the strict policy of accountability for the generation and collection of revenue that lead the economy on the path of prosperity.

There are certain limitations of this study that give scope for further research. Firstly, quarterly data is not available for government revenue and expenditure in Pakistan. Therefore, interpolation methods are used that mechanically distribute annual into quarterly. However, other methods can be used to interpolate data from annual into quarterly e.g. Paredes $e t$ al. (2014). Secondly, DSGE model can be used to analyze the effects of fiscal policy shocks on macroeconomic variables in Pakistan. 


\section{Appendix A. Construction of Quarterly Data}

Data of government expenditures and revenues are available at annual frequency, while interest rate is available at quarterly frequency. However, there are various methods to interpolate the data. This study used Denton (1971) method to interpolate the annual data into quarterly data. Denton procedure levies the condition that sum of interpolated series must equal to the annual series of that particular year. Denton method is well-suited, simple and robust for large scaled application (IMF, 2017). Denton method uses quadratic minimization framework to minimize the distance between the two series.

On the other hand, Chow and Lin (1971) uses multivariate regression based procedure for temporal disaggregation. Chow-Lin method describes the linear association among quarterly and monthly series of a variable. Denton method is preferred over other methods due to following reasons (IMF, 2017). It is substantially easier to implement. It provides elegant and simple framework for extrapolation. It incorporates the existence of any systematic bias or lack thereof in year to year rate of change. It is more preferable when one or more correlated high frequency series are available.

Table A1 reports the variance equality test between actual (annual) data and interpolated quarterly data. The variance equality test is applied on all the three specifications for robustness check. The results show that null hypothesis of equal variance can not be rejected in all three cases. Hence, the results are robust to annual data as well as quarterly data.

Table A1

RESULTS OF VARIANCE EQUALITY TEST

\begin{tabular}{lccc}
\hline \multicolumn{1}{c}{ Variable } & Annual $\boldsymbol{v s}$ Denton & Annual $\boldsymbol{v s}$ Chow-Lin & Denton $\boldsymbol{v s}$ Chow-Lin \\
\hline GDP & 1.0008 & 1.0457 & 1.0465 \\
& $(0.9960)$ & $(0.7747)$ & $(0.7709)$ \\
\hline Prices & 1.0010 & 1.0406 & 1.0417 \\
& $(0.9946)$ & $(0.7989)$ & $(0.7935)$ \\
\hline Total Expenditure & 1.0059 & 1.0246 & 1.0307 \\
& $(0.9693)$ & $(0.8763)$ & $(0.8461)$ \\
\hline Total Revenue & 1.0069 & 1.0302 & 1.0374 \\
& $(0.9644)$ & $(0.8485)$ & $(0.8138)$ \\
\hline
\end{tabular}

Note: p-values are in parenthesis. 


\section{Appendix B. Construction of Exogenous Fiscal Elasticities}

Blanchard and Perotti (2002) argued that it is necessary to identify the fiscal shocks outside the VAR model to examine the contemporaneous elasticities of fiscal variables with respect to macroeconomic variables. Therefore, exogenous elasticities have been estimated outside the VAR model as recommended by Blanchard and Perotti (2002). The elasticities of expenditure and the respected disaggregate components with respect to GDP is considered to be zero. Because it is assumed that government expenditures do not respond to real GDP within a quarter as expenditures are predetermined in budgetary plan and inflexible in short run (Tenhofen et al., 2010). To estimate the elasticity of revenue and its sub-components with respect to GDP in Pakistan, the study follows Bilquees (2004).

However, the elasticities of fiscal variables with respect to prices (GDP deflator) are simply the elasticities of fiscal variables with respect to GDP less 1. Expenditures and revenues are insensitive to interest rate, therefore the elasticities of expenditure and revenue with respect to interest rate is considered to be zero. Fluctuations in interest rate have minute impact on government expenditure through the payments on debt because small portion of debt is covered in quarterly period of time (Tenhofen et al., 2010). The exogenous elasticities of the fiscal variables used in the identifications of fiscal shocks in the SVAR model are given in table B1.

Table B1

EXOGENOUS ELASTICITIES OF FISCAL VARIABLES WITH RESPECT TO GDP, PRICES, AND INTEREST RATE

\begin{tabular}{lllc}
\hline \multicolumn{1}{c}{ Variable } & $\begin{array}{c}\text { Elasticity w.r.t } \\
\text { GDP }\end{array}$ & $\begin{array}{c}\text { Elasticity w.r.t } \\
\text { Prices }\end{array}$ & $\begin{array}{c}\text { Elasticity w.r.t } \\
\text { Interest Rate }\end{array}$ \\
\hline Total Expenditure & 0 & -1 & 0 \\
Total Revenue & 0.8703 & -0.13 & 0 \\
\hline Disaggregate Expenditure & & -1 & 0 \\
\hline Current Expenditure & 0 & -1 & 0 \\
Developmental Expenditure & 0 & & 0 \\
\hline Disaggregate Current Expenditure & & -1 & 0 \\
\hline Defence Expenditure & 0 & -1 & 0 \\
Subsidies & 0 & -1 & 0 \\
Social Services & 0 & & 0 \\
\hline Disaggregate Revenue & & -0.1838 & 0 \\
\hline Tax Revenue & 0.8162 & 0.4024 & 0 \\
Non-Tax Revenue & 1.0424 & & 0.3594 \\
\hline Disaggregate Tax Revenue & & -0.36 & 0 \\
\hline Direct Tax & 1.3594 & & 0 \\
Indirect Tax & 0.6435 & -0.8139 & 0 \\
\hline Disaggregate Indirect Tax & & 0.9381 & \\
\hline Excise Duty & 0.1861 & -0.9864 & \\
Sales Tax & 1.9381 & -0.19 & \\
Tax on International Trade & 0.0136 & & \\
Surcharges & 0.8199 & & \\
\hline
\end{tabular}




\section{References}

Alesina, A. F., Favero, C. and Giavazzi, F. (2018), "What Do We Know About The Effects of Austerity?", NBER Working Paper 24246. National Bureau of Economic Research.

Ali, S. and Ahmed, N. (2010), "The Effects of Fiscal Policy on Economic Growth: Empirical Evidences Based on Time Series Data from Pakistan", Pakistan Development Review, 44(4): 497-512.

Amisano, G. and Giannini, C. (1997), Topics in Structural VAR Econometrics, Springer.

Aschauer, D. A. (1989), “Is Public Expenditure Productive?”, Journal of Monetary Economics, 23(2): $177-200$.

Auerbach, A. J. and Gorodnichenko, Y. (2012), "Measuring the Output Response to Fiscal Policy", American Economic Journal: Economic Policy, 4(2): 1-27.

Baxter, M. and King, R. G. (1993), "Fiscal Policy in General Equilibrium”, American Economic Review, 83(3): 315-334.

Bilquees, F. (2004), "Elasticity and Buoyancy of the Tax System in Pakistan", Pakistan Developent Review, 43(1): 73-93.

Blanchard, O. and Perotti, R. (2002), "An Empirical Characterization of the Dynamic Effects of Changes in Government Spending and Taxes on Output", Quarterly Journal of Economics, 117(4): 13291368 .

Burnside, C., Eichenbaum, M. and Fisher, J. D. (2000), “Assessing the Effects of Fiscal Shocks", NBER Working Paper 7459, National Bureau of Economic Research.

Chow, G. C. and Lin, A. (1971), "Best linear unbiased interpolation, distribution and extrapolation of time series by related series", Review of Economics and Statistics, 53(4): 372-375.

De Castro, F. (2006), "The Macroeconomic Effects of Fiscal Policy in Spain", Applied Economics, 38(8): 913-924.

De Castro, F. and De Cos, P. H. (2008), "The Economic Effects of Fiscal Policy: The Case of Spain", Journal of Macroeconomics, 30(3): 1005-1028.

Denton, F. T. (1971), "Adjustment of monthly or quarterly series to annual totals: An approach based on quadratic minimization”, Journal of the American Statistical Association, 66(333): 92-102.

Edelberg, W., Eichenbaum, M. and Fisher, J. D. M. (1999), "Understanding the Effects of a Shock to Government Purchases", Review of Economic Dynamics, 2(1): 166-206.

Fatas, A. and Mihov, I. (2001), "The Effects of Fiscal Policy on Consumption and Employment: Theory and Evidence", CEPR Discussion Paper 2760.

Favero, C. (2002), "How do European monetary and fiscal authorities behave?", CEPR Discussion Paper 3426.

Gali, J., Valles, J. and Lopez-Salido, J. D. (2007), “Understanding the Effects of Government Spending on Consumption", Journal of the European Economic Association, 5(1): 227-270.

Giordano, R., Momigliano, S., Neri, S. and Perotti, R. (2007), “The Effects of Fiscal Policy in Italy: Evidence from a VAR Model”, European Journal of Political Economy, 23(3): 707-733.

Hamilton, J. D. (1994), Time Series Analysis, Princeton University Press, Princeton. 
Hemming, R., Mahfouz, S. and Schimmelpfennig, A. (2002), "Fiscal Policy and Economic Activity During Recessions in Advanced Economies", IMF Working Paper 02/87, International Monetary Fund.

Holmes, J. and Hutton, P. (1990), “On the Causal Relationship Between Government Expenditures and National Income", Review of Economics and Statistics, 72(1): 87-95.

IMF (2017), Quarterly National Accounts Manual, Washington: International Monetary Fund.

Khalid, M., Malik, W. S. and Sattar, A. (2007), "The Fiscal Reaction Function and the Transmission Mechanism for Pakistan”, Pakistan Institute of Development Economics, 46(4): 435-447.

Kilian, L. (1998), “Small-Sample Confidence Intervals for Impulse Response Functions”, Review of Economics and Statistics, 80(2): 218-230.

Lutkepohl, H. (2005), New Introduction to Multiple Time Series Analysis, Berlin: Springer-Verlag.

Lutkepohl, H. and Kratzig, M. (2004), Applied Time Series Econometrics, Cambridge University Press, Cambridge.

Mountford, A. and Uhlig, H. (2009), "What are The Effects of Fiscal Policy Shocks?", Journal of Applied Econometrics, 24(6): 960-992.

Munir, K. and Riaz, N. (2019a), "Fiscal Policy and Macroeconomic Stability in South Asian Countries", Hacienda Pública Española/Review of Public Economics, 228(1): 13-33.

Munir, K. and Riaz, N. (2019b), "Macroeconomic Effects of Fiscal Policy in Pakistan: A Disaggregate Analysis", Applied Economics, 51(52): 5652-5662.

Munir, K. and Sultan, M. (2018), "Are Some Taxes Better for Growth in Pakistsan?, A Time Series Analysis”, International Journal of Social Economics, 45(10): 1439-1452.

Paredes, J., Pedregal, D. J. and Perez, J. J. (2014), "Fiscal policy analysis in the euro area: Expanding the toolkit", Journal of Policy Modeling, 36(5): 800-823.

Perotti, R. (2005), "Estimating the Effects of Fiscal Policy in OECD Countries", CEPR Discussion Paper 4842, Centre for Economic Policy Research.

Phillips, P. C. B. (1998), "Impulse Response and Forecast Error Variance Asymptotics in Nonstationary VARs", Journal of Econometrics, 83(1-2): 21-56.

Popa, I. and Codreanu, D. (2010), "Fiscal Policy and its Role in Ensuring Economic Stability", MPRA Paper 20820, Munich Personal RePEc Archive.

Ramey, V. A. and Shapiro, Z. D. (1998), "Costly Capital Reallocation and the Effects of Government Spending”, Carnegie Rochester Conference Series on Public Policy, 48: 145-194.

Romer, C. D. and Romer, D. H. (2014), "The Incentives Effect of Marginal Tax rates: Evidence from the Interwar Era”, American Economic Journal: Economic Policy, 6(3): 242-281.

Subhani, M. I. and Ali, J. (2010), "Impact of Fiscal Policy on the Economy of Pakistan", South Asian Journal of Management Sciences, 4(1): 14-22.

Tenhofen, J., Wolff, G. B. and Heppke-Falk, K. H. (2010), "The Macroeconomic Effects of Exogenous Fiscal Policy Shocks in Germany: A Disaggregated SVAR Analysis”, Journal of Economics and Statistics, 230(3): 328-355. 


\section{Resumen}

En este artículo se analizan los efectos de la política fiscal en un conjunto de variables macroeconómicas para la economía de Pakistán. El enfoque metodológico es un SVAR y el periodo analizado comprende desde 1976:Q1 hasta 2018:Q4. Para la identificación de las crisis fiscales se utilizan las elasticidad impositivas, así como los retardos temporales en la formulación de políticas públicas en relación con la actividad económica. Los resultados muestran que un aumento del gasto público en desarrollo supone un mayor aumento en el PIB real que un aumento del gasto corriente, a su vez este último provoca inflación mientras que el primero la reduce. El nivel de precios guarda una relación positiva con las transferencias y con el gasto en defensa, mientras que el gasto en servicios sociales la reduce. Los ingresos de carácter tributario aumentan el PIB real en mayor medida que los ingresos de carácter no tributario. Ambos tipos de ingresos incrementan el nivel de precios y reducen el tipo de interés. Un incremento en la recaudación de los impuestos directos disminuye el PIB real, provoca inflación y eleva el tipo de interés. Los impuestos indirectos guardan una relación positiva con el PIB real pero negativa con el tipo de interés. Un aumento en los impuestos especiales, en el impuesto sobre las ventas y en el impuesto sobre el comercio internacional provoca inflación. Nuestros resultados confirman que el aumento en la producción consecuencia de una política fiscal expansiva tiene costes en términos de inflación, confirmando la teoría de estabilización keynesiana de la política fiscal. Es necesario que el gobierno canalice el incremento en el gasto hacia gastos productivos, al tiempo que adopta una política estricta de rendición de cuentas que permita a la economía recuperar la senda de la prosperidad.

Palabras clave: política fiscal, gastos del gobierno, ingresos del gobierno, SVAR, Pakistán.

Clasificación JEL: C32, E62, H30. 
